\title{
N. F. S. Grundtvigs bopæle (adresser) i København.
}

\author{
Ved Steen Johansen.
}

\section{Indtil 1821 .}

Forstander Ernst J. Borup ytrede engang til undertegnede, at man savnede en fuldstændig fortegnelse over N. F. S. Grundtvigs bopæle eller adresser. Hermed gøres et forsøg på at afhjælpe dette savn, dvs. præcisere og supplere den viden eller de antydninger, man $\mathrm{i}$ forvejen har derom. Dog begrænser jeg opgaven til at gælde Grundtvigs bopæle i Kobenhavn, idet der ses bort fra hans ferier og rejser. Undtagelsesvis drøftes dog visse spørgsmål om Gr.s bopæle og rejser i hans drengeår i Tyregod og Arhus. Iøvrigt er det, der meddeles i det følgende, ikke studier i topografi, matrikelnumre eller bygningshistorie, men kun nogle bemærkninger til Gr.s biografi. Der gøres flere svinkeærinder for at oplive det noget tørre emne.

En trykt liste over Grundtvigs adresser i København findes for så vidt allerede i bogen »Minderige Huse. Kendte Mænds og Kvinders Boliger. Uddraget af Kjøbenhavns Vejvisere I770-1870«. Kraks Vejviser. Kjøbenhavn. (1922), s. I46, men denne liste begynder først med årene 1816-17, dvs. da Gr. første gang kom i vejviseren ${ }^{1}$ ). Endvidere anføres $\mathrm{i}$ omtalte liste kun årstallene for hver adresses varighed, men ikke den nøjere angivelse af tiden for til- og fraflytninger. Der er således årsag nok til nye undersøgelser på dette område.

Om den unge Grundtvigs opholdssteder, indtil han i oktober 1800 kom til København for at tage studentereksamen, ved vi vistnok så god besked, som det er muligt ud fra det ret sparsomme materiale, der er os overleveret. Derfor kan vi takke F. Rønning, som i sin bog »Den grundtvigske slægt《 (1904) har fundet ud af mange ting; denne bog er i det hele en af Rønnings bedste. Et par punkter er dog stadig lidt dunkle. Først det nøjere tidspunkt for Gr.s ankomst til Tyregodlund præstegård. Gr. kom til Tyregod fra Udby i I 792, men hvornår i dette år? Her er den mærkelighed, at L. Schrøder (i »N.F.S. Gr.s Barndom og første Ungdom«, I883, s. 52), J. Richter

1) Københavns vejviser udkom også dengang hvert år, hver årgang med sit årstal, men undtagelsesvis havde de seks bind, der udsendes 18 I 4-20 på $^{-20}$ titelbladet angivelsen $1814-15,1815-16$ osv. Fra og med 1820 atter kun ét årstal på hvert titelblad ligesom $\mathrm{i}$ tiden før 1814 . 
(i Højskolebladet 25. dec. I896) og Rønning (i førnævnte bog s. 79) alle mener, at ankomsten fandt sted i foräret $\mathrm{I}_{792}$, Schrøder angiver endda: senest i nævnte forår, medens Richter præciserer det til, at Gr. var $8^{1 / 2}$ år gammel, da det skete, hvilket jo må give marts 1792 som tidspunkt. Dette er dog en ganske uhjemlet gisning. I sit store værk om Gr. (I907-I4) udtrykker Rønning sig også langt forsigtigere, idet han alene angiver »8-9 års alderen« (I, I, s. 6). Dette er dog lidt for upræcist igen. Men hvad siger Gr. selv derom? I sin til leksikografen Th. H. Erslew sendte livsoversigt, vel senest fra 1843 , skriver han: $\gg 9$ Aar gammel kom (Gr.) til Jyllands sorte Hede, hvor han (I792-98) voxde op hos Præsten L. Feld i Thyregod « ( Gr.s Erindringer ...« 1948, s. 15$\left.)^{2}\right)$. Udtalelsen »9 Aar gammel《 kan vel kun fortolkes på én måde: Gr. må være fyldt 9 år, må altså have passeret datoen 8. sept. I792, da ankomsten fandt sted. Gr. taler selv (i sine selvbiografiske optegnelser til Molbech I839, se Molbech-Gr.s brevveksling I888, s. 219) om »de 6 Aar paa Heden«, hvad der naturligt må opfattes som seks fuldstændige år, eller så omtrent, altså fra efteråret $179^{2}$ til (sidste halvdel af) sept. 1798 . Vi ved nemlig fra Gr. selv, at pastor Feld ledsagede Gr. til Århus (Udv. Skr. I, s. I7) i sept. I798, og de er altså kommet fra Tyregod. (Jf. også at Gr. i »Mands Minde« 1877 , s. 270 udtaler, at han var i Tyregod, til han »var fulde femten «, altså i det mindste til sept. I798). - I Tyregod har Gr. boet i selve præstegården, i en bygning, som nu ikke eksisterer (jf. Richter anf. st.), og hver sommer i disse år besøgte han Udby (jf. Molb.-Gr.s brevveksling anf. st.).

Et andet, mere dunkelt punkt er de forskellige rejser $i$ Jylland, som Gr. under sit Tyregod-ophold foretog sammen med pastor Feld. Herom må henvises til de yderst sparsomme oplysninger hos Schrøder ( 1883 ), med suppleringer og gætninger af Rønning ( 1904 ). Vi noterer da, som et slags kuriosum, at landsbyen Navtrup i den nordlige del af Salling er det nordligste sted i Danmark, Gr. nogen sinde har besøgt. Under denne rejse passerede han Skive, og Gr. kunde endnu som gammel, som han selv fortæller (jf. Schrøder s. 63), erindre de talrige storkereder på tagene i denne by. Jeppe Aakjær mener at vide ( $\mathrm{I} \gg$ Bogen om Skive«, I 926 , s. 502), at denne nørrejyske rejse fandt sted i I794, men hvorfra han har dette årstal, oplyser han beklageligvis ikke. Ligeledes må Rønnings mangel på kildeangivelser vedrørende Gr.s jyske rejser som dreng beklages ${ }^{3}$ ).

2) Lignende også i Gr.s af Erslew let retoucherede tekst i dennes forfatterleksikon I ( 1843 ), s. 508.

3) De sparsomme kildeangivelser overalt i Rønnings Grundtvig-værk og ligeså $i$ »Den grundtvigske slægt« (egentlig kun et indledende bind til det større værk) kan i høj grad være generende for forskere. Men det betyder ikke, at dette værk ikke skulde være bygget på grundige kildestudier. Rønnings efterladte »Samlinger til Bogen om Grundtvig《 (8 voll., Ny kgl. Saml. $\left.3191.4^{0}\right)$ viser os klart, at han $\mathrm{i}$ høj grad har drevet arkivalske studier foruden en vidtstrakt læsning. I disse papirer kan man $i$ en del tilfælde finde frem til R.s kilder. Forskelligt om pastor Feld og om præstegården i Tyregod har R. således fundet i »Gejstlig Skifteprotokol for Nørvang Herred《 og »Nørvang Herreds (gejstlige) Correspondance 1790-1812《, 
Med hensyn til Gr.s ophold $i$ Arhus 1798-180o melder sig først og fremmest det hidtil ubesvarede spørgsmaal om, hvor Gr. har boet, medens han gik i latinskolen. Ingen af de efterhånden temmelig mange, der har skrevet om Gr. i Århus, synes at have undersøgt dette, vel fordi man har regnet spørgsmålet for uløseligt. Man har alene henvist til et par udtalelser af Gr. selv som følger: »I den første Vinter tilbragde jeg regelmæssig mine Aftener som Forelæser paa et lille Skomager-Værksted i Huset hvor jeg logerede, og lærde derved først at kiende vore gamle Almue-Bøger (Molb.-Gr.s brevveksling I888, s. 219), samt »jeg mindes endnu med Fornøielse, hvordan jeg, som Latinsk Skoledreng læste gamle Danske Krøniker om Aftenen paa et Skomager-Værksted« (Skolen for Livet og Academiet i Soer, I838, s. 66). Dette er vist alt, hvad Gr. har ytret om sin bolig i Århus. Han har logeret hos en skomager, men hos hvem? Den I. febr. I80 I afholdtes en almindelig folketælling i Danmark, og folketællingsprotokollen for Århus (i Rigsarkivet) viser, at der i byen i I80 I levede i alt 4104 personer, fordelt på 940 familier. Der fandtes dengang ca. 26 selvstændige skomagere (skomagermestre, skomagere, skoflikkere) i Århus, hvortil kom nogle skomagersvende samt læredrenge boende hos enkelte af mestrene. Man kan af folketællingen se, hvilke af skomagerne havde logerende. Hvis man nu i r8or finder, at en skomager f. eks. har haft en eller flere latinskoleelever som logerende, er det nærliggende at tro, at han ogsaa har haft sådan(ne) i årene I798-180o. Imidlertid finder man, at ingen skomager i 180 I har haft latinskoledrenge boende hos sig, og at kun yderst få skomagere i det hele taget har haft logerende. Men der er en ejendommelig omstændighed, som bør anmærkes. Latinskolen lå i Skolegade nr. 42 (iflg. daværende nummerering), og det viser sig nu, at der i huset ved siden af, nr. 4I, boede en skomagermester ved navn Hans Hendrik Nordmand med kone og fire børn og en skomagersvend. $\mathrm{Nu}$ er der ved Gr.s Århus-erindringer den ejendommelighed, at det er, som om han kun erindrer skolen, dens lærere, livet på skolen og skolens bibliotek, kun skolen synes at have eksisteret for ham, han erindrer aldrig andet fra Århus! Her ses dog bort fra de to små citater om skomagerværkstedet samt den flygtige og eneste omtale af den tæt ved skolen beliggende domkirkes gyldne spir, jf. digtet »Udby Have«. Naturligvis ved Gr. meget om Århus, jf. nævnte digt, men det er en ganske anden sag. Hovedindtrykket bliver, at det er, som om Gr. udelukkende har levet på eller ved skolen - har tilbragt sin meste tid i dens umiddelbare nærhed. Kan han have boet hos nævnte skomager?

Sammen med Gr. blev kun to andre dimitteret fra Århus i efteråret 1800 . Deres navne var Bøgild ( 18 år) og True (20). Om deres videre skæbne kan anmærkes følgende. Peter Bøgild lod sig i efteråret 1800 indskrive ved Københavns universitet som teologisk student ligesom Gr. og True, og

jf. vol. III af R.s papirer. (Men hvor disse kilder befinder sig, har han ikke noteret.) - En anden sag er, at R. i sin Grundtvig-biografi ikke sjældent lader fantasien løbe lovlig stærkt m. h. t., hvad Gr. kan have tænkt og følt ved forskellige lejligheder. Herpå gives et par eksempler i det følgende. 
han bestod i april I8or, ligesom de to andre, den filosofiske prøve, men derefter tog han vistnok ikke flere eksamener ved universitetet, og om hans senere liv vides foreløbig intet sikkert. Om Thomas True er vi noget bedre underrettet. Gr. og True synes at have holdt sammen i København i begyndelsen af studentertiden. Begge valgte - ligesom Bøgild - professor Gamborg til privatpræceptor, begge bestod i i8o I henholdsvis den filosofiske og den filologiske prøve, og i i8o I finder vi dem begge boende i samme logi, nemlig i Lille Brøndstræde nr. I62. (Mere om denne bopæl i det følgende.) Hvor længe de har boet sammen, ved vi ikke. Thomas True fik ellers en temmelig tragisk skæbne. Han blev teol. kandidat i 1805 , derefter degn i Odder I809-25. Fra nu af kan vi med et citat oplyse om resten af hans liv: »(True) stod her (i Odder) $\mathrm{i}$ et spændt forhold til præst og kirkepatron, og blev derhos daglig mishandlet af en arrig kone; forfaldt så slemt til drik, og blev nu på sin kones anklage ej alene suspenderet, men i sit eget hus indespærret som afsindig, under dag- og nattevagt af sognebeboerne; nedlagde 1825 sit æmbede, blev skilt fra kone og omgivelser, og kom herved atter i ro og orden; blev s. å. hjælpepræd. hos H. F. Brandt i Katrup, Ø. og T., siden hos H. D. Friis i Vejle og H.; gjenvandt i høj grad foresattes og omgivendes velvillie og agtelse ved et dadelfrit levnet og en ordentlig og dygtig æmbedsførelse; derpaa hjælpep. hos J. Gjelstrup i Skærbæk 21. feb. 27 , p. i Guldager 20/2 29, $\dagger$ 24. feb. 47 efter nogle års svagelighed på grund af en uheldig væltning; kunde dog selv forrette sit æmbede til det sidste« (Frederik Barfod: Danmarks Gejstlighed I, I848, s. 205). - Grundtvig synes aldrig at have omtalt True, og om True nogen sinde skriftligt har forsøgt at sætte sig i forbindelse med Gr., er foreløbig uvist.

Grundtvig forlod Århus i september I80o og tog i oktober samme år studentereksamen ved universitetet i København. Han rejste til hovedstaden via Udby, hvor han aflagde »et koldt og kort Besøg«i sit forældrehjem. Denne oplysning kendes vist kun fra Køsters og Schrøders bog om Povel Dons (1875), s. 9, uden angivelse af kilde. Formodentlig har Køster oplysningen fra Gr. selv. Når Gr. på ældre dage har karakteriseret dette besøg som »koldt«, ser han det altså i samme lys som sin skolegang i Århus, som han på ældre dage som bekendt heller ikke havde noget godt at sige om. (Allerede 18 I I står skolegangen for Gr. som »slem《). Men Gr.s senere udtalelser om sin Århus-tid - og også karakteristikken af dette besøg i Udby - må bedømmes og benyttes med stor forsigtighed - som så mange af Gr.s erindringer om sig selv. (I virkeligheden klarede Gr. skolen som en leg; ved oprykningen i I 799 blev han rost i hele skolens påhør (jf. Udv. Skr. I, s. I8); han vandt sig tilmed et par gode venner blandt lærerne). Man må derfor tage afstand fra alt, hvad Rønning - i den senere Gr.s ånd - digter sammen om dette besøg i Udby og om rejsen til København i I8oo (I, I, s. 7-9).

I de følgende fem år, indtil afrejsen fra Udby til Langeland i marts I805, førte Grundtvig rent opholdsmæssigt et forbavsende omflakkende liv, ikke så meget fordi han hyppigt skiftede adresser i København, for det gjorde han efter alt at dømme ikke, men på grund af sine mange ophold i Sydsjælland eller Falster (Udby, Torkilstrup og andre steder). Denne ydre uro må vel fortolkes som et udslag af en ikke almindelig rastløshed, som dengang 
åndeligt også afspejlede sig $\mathrm{i}$ de mange genrer, han som begyndende forfatter forsøgte sig i. Det teologiske studium lagde ikke stort beslag på hans kræfter (han begyndte først rigtigt derpå i foråret I803, jf. Udv. Skr. I, s. I06), og han tog sig endda tid til, midt under eksamenslæsningen i efteråret $\mathrm{I} 8 \mathrm{o}_{3}$, at optræde to gange som amatørskuespiller (jf. Grundtvig-Studier 1956, s. 83 f.). Sine mange besøg i hjemmet i Udby eller hos broderen i Torkilstrup eller hos pastor Blicher i Gundslev har han m. h.t. afrejse- og ankomstdatoer oftest omtalt så kortfattet i sine tilmed ufuldstændigt bevarede dagbøger, at en virkelig »kortlægning « af disse rejser vist ikke mere lader sig foretage.

Angående Gr.s bopale $i$ København 1800-04 (i 1805 var han overhovedet ikke i København) kan først anmærkes Rønnings oplysning: »Gr.s første bolig i København kender vi ikke; men han flyttede senere hen i Lille Brøndstræde (nr. r62), også på den tid et alt andet end fashionabelt kvarter. I samme hus boede Thomas True, der var dimitteret fra Århus sammen med ham《 (I, I, s. 9 fodnote). Om True er fortalt ovenfor. Den anførte adresse i Lille Brøndstræde nr. I62 (efter I807: mtk. nr. 107; efter 1859: gade-nr. 13; kvarteret nedrevet 1909) kendes også fra folketællingen I8or, hvor vi ser, at Gr. sammen med True logerer hos en skræddermester Hans Jacob Møller, dengang 34 år gammel og gift. Men hvorfra ved Rønning, at Gr. først senere - og ikke straks i oktober I80o - fik sin bopæl i Brøndstræde? Netop dette, at Gr. boede sammen med en skolekammerat, tyder dog på, at de begge også har boet der straks fra begyndelsen af Københavnsopholdet. De har søgt logi sammmen og foreløbig fundet et $\mathrm{i}$ Brøndstræde. En formodning om, hvor Gr. har boet, er i 1930 fremsat af Hertha Fribert som følger: »Man ved ikke, hvor Gr. boede den første Tid, fra han som ung Student i I800 kom til Kbhvn., og til han et Par Maaneder efter kom til at logere i Brøndstræde; men det har sikkert været hos Majorens, der dengang boede i St. Kongensgade Mtk. Nr. 5I; hos dem boede ligeledes efter hinanden Niels Chr. og Otto Grundtvig ... samtidig med, at de var Informatorer for L. Fribert og hans yngre Bror. Naar Gr. kalder L. Fribert for sin »Barndoms- og Ungdomsven«, saa har han jo nok, da han nedskrev dette i sine »Kvædlinger«, stiltiende ogsaa tænkt paa de Goder, han som fattig Student havde nydt i hans Hjem « (Optegnelser i Anledning af Hundredaarsdagen for F. W. Trojel Fribert's Fødsel. I8ı-19io. Kbh. 1930, S. 31). - Hertha Friberts udtalelse om Brøndstræde støtter sig sikkert på Rønning. Formodningen om logiet hos majoren er interessant og bør overvejes. »Majorens« vil sige Gr.s morbroder, landeværnsmajor Carl Vilhelm Bang ( $1754^{-1} 806$ ). Han boede i Store Kongensgade, nuvær. nr. 57-59. Som hovedrig mand levede han her som husbond for en større flok pårørende, tjenestefolk og logerende. Folketællingen I8o i opremser følgende foruden ham selv: hans (anden) kone Anne Marie Bang, f. Madsen (enke efter brygger Fribert), Bangs stedsønner Lorentz (20 år gl.) og Lars Jacob Fribert ( I4 år), brodersønnen Carl Vilhelm Bang ( 7 år); som logerende anføres Niels Christian Bang Grundtvig, N.F. S. Gr.s ældre broder, 24 år gl., ugift, student (således i folketællingslisten; han var dog i 1800 blevet teologisk kandidat). Desuden en husjomfru, to tjenestepiger og en tjener. Hvad nu rigtigheden af 
Hertha Friberts oplysninger angår, må først bemærkes, at Otto Gr. må have boet hos major Bang for Niels Christian, og ikke omvendt, idet Otto blev student 1789, mens Niels Christian først blev det i i796. Men om Gr. virkelig har logeret hos Bang i efteråret $\mathrm{I} 800$ er højst tvivlsomt - af følgende indirekte grunde. I forvejen logerede som anført en af hans brødre; mon der har været plads til endnu en logerende? I sin »omarbejdede dagbog « oplyser Gr. (Udv. Skr. I, s. 2I) ved omtalen af sine økonomiske forhold i begyndelsen af sin studentertid, at han foruden penge fra andre også hver måned modtog 2 rdl. fra nævnte morbroder C. V. Bang. Vilde Bang have givet Gr. disse penge, hvis denne havde boet hos ham? Næppe. Og hvorfor daglig spise middag hos en anden morbroder (prof. F. L. Bang på Frederiks hospital, jf. smst.), hvis han boede hos G. V. Bang? Alt tyder på, at Gr. har boet selvstændigt, og, som før antydet, straks fra begyndelsen i Lille Brøndstræde. Det var ganske vist ikke en fin gade, måske netop derfor omtaler han den ikke i dagbogen! Hertha Friberts henvisning til, at Gr. har kaldt Lorentz Fribert for sin »Barndoms- og Ungdomsven《 (rettere: »en af min Barndoms og Ungdoms Venner«, Udv. Skr. I, s. 756) behøver ikke at betyde, at $\mathrm{Gr}$. har boet $\mathrm{i}$ hus med ham.

Inden vi forlader major Bang, skal vi gøre opmærksom på en lille omstændighed, som ganske vist ikke angår adresser, men alligevel kom til at berøre familien Grundtvig, og det på en glædelig måde. C. V. Bang havde i I789 ægtet føromtalte bryggerenke, som var blevet endog særdeles velstående takket være arv både fra sin fader og sin første mand. I I806 dør Bang og i 1807 hans hustru, og arven efter dette ægtepar deltes således, at ca. halvdelen tilfaldt hustruens slægtninge, og halvdelen (ca. 43.0oo rdl.) major Bangs ditto. Derved arvede en lang række af slægten Bang store summer (jfr. Hertha Friberts optegnelser s. 63 f.), bl. a. også Gr.s moder, hvis andel var 3014 rdl. Allerede før hele indboet var opgjort, fik hun, i I808, i forskud udbetalt $2000 \mathrm{rdl}$. Sikkert har disse penge voldt stor glæde i præstehjemmet i Udby, som få år før, omkr. I8oo, havde været sin økonomiske undergang nær (se herom Rønning: Den grundtvigske slægt, I904, s. 54 f.). Da Gr. i I8I I skulde ordineres til præst i Udby, kunde faderen derfor tillade sig at forære sønnen $200 \mathrm{rdl}$. bl. a. til køb af en præstekjole (se brev nr. 25 i Breve fra og til N.F.S. Gr. I), en foræring, der næppe kunde have fundet sted uden den Bang'ske arv. - En anden af Bang-slægten, der blev meget glad for sin arveandel, var Henrik Steffens, som netop kom på besøg i København, da hans tante skulde begraves. Herom - og om hele denne arvehistorie - fortæller han ret udførligt i sine erindringer »Was ich erlebte« V ( 1842 ), s. 257 (s. 253 ff.).

Gr. boede altså i ı8o i i Lille Brøndstræde. Hvor længe han har boet der, ved vi ikke. I sin dagbog for 29. nov. 1803 omtaler han sin gæld på 20 rdl. til urtekræmmer Zimmer (Udv. Skr. I, s. 45). Denne boede iflg. Vejviseren i Springgade 42 (Efter den nye matrikulering I807: nr. 4). Springgade var indtil I88 I navnet på den del af Pilestrædet, som gik fra Møntergade til Landemærket, og nr. 42 (ell. 4) svarer til nuvær. nr. 58 i Pilestræde, Lille Brøndstræde lå ganske nær derved (hvor nu Gutenberghus ligger), hvad der tyder på, at Gr. har boet i denne gade endnu i nov. 1803 . 
I tidsrummet fra $180 \mathrm{I}$ og til efteråret $\mathrm{I} 804$ kender vi med sikkerhed kun to andre Gr.-adresser i hovedstaden. Den 25. august 1804 skriver Gr. nemlig i sin dagbog følgende: »I Dag flyttede Jeg fra Pilestræde IIo hid i Hyskenstræde 38 og 39 til min Fætter Trøyel« (Udv. Skr. I, s. 63). For at sætte dette adresseskifte $\mathrm{i}$ den rette belysning er det måske bedst først at give et omrids af Gr.s færden fra slutningen af 1803 til forår I805. Gr. rejser i slutningen af nov. 1803 fra København (Udv. Skr. I, s. 45). Rimeligvis var denne afrejse hans endelige farvel til bopælen i Lille Brøndstræde. Fra nu af og indtil sommer 1804 opholder han sig dels i Torkilstrup, dels i Udby. Derefter følger ca. to sommermåneder i København, hvor han først en kortere tid bor hos sin ven P.N. Skovgaard i Pilestræde i Io (efter 1807: mtk. nr. 89; nuvær. gade-nr. 27), derefter hos sin fætter Trojel i Hyskenstræde 38-39 (efter 1807: mtk. nr. I43; nuvær. nr. 8), således som anført i dagbogen. Den 8. september rejser Gr. hjem (fasc. 245,2). I oktober nødes han til, for at forhandle om en huslærerstilling, at rejse på et fjorten dages besøg i København. Om han under dette besøg har boet hos Trojel, ved vi ikke, men det er rimeligt. Disse fjorten dage må have været tiden omkr. slutn. af oktober og begyndelsen af november. I nov. må Gr. være rejst hjem, og dermed forlod han Kbh. for ikke at gense byen før i maj 1808 , altså henved $3^{1 / 2}$ år efter sommeropholdet $\mathrm{i}$ 1803, når bortses fra de førnævnte fjorten dage. Denne tidsangivelse: $3^{1 / 2}$ år, fremhæver vi her, thi vi møder den igen senere.

Førnæunte fætter »Trøyel«, som Gr. også omtaler to andre steder i sine dagbøger (Io. sept. I803, utrykt, og 31. dec. 1804: Udv. Skr. I, s. 69), hed Jacob Thomas Trojel ( 1782-1859), ældste søn af kgl. godsinspektør i Odsherred og landøkonomisk forfatter Frantz Vilhelm Trojel (1746-1819), der var af præsteslægt. Betegnelsen »fætter《 anvender Gr. her lidt frit, blot $i$ betydningen: en noget fjernere ( $o g$ med en selv nogenlunde jævnaldrende) mandlig slægtning. Slægtskabet var dette, at Jacob Thomas' moder var en datter af Gr.s mormoder Ulrikke Eleonore Schwane i dennes andet ægteskab. Gr. og han har således haft fælles mormoder, men ikke morfader. Jacob Thomas Trojel, der var student fra 1803 , blev senere ejer af hovedgården $\gg$ Vaar $\ll$ Jylland (jf. Danske Slotte og Herregaarde III ( I943), s. 687 ff.). Forøvrigt var denne slægtsforbindelse mellem de to »fætre« ikke den eneste. Jacob Thomas havde i 1802 ægtet en søster til den tidligere nævnte Lorentz Fribert, stedsøn af Gr.s onkel major Bang. Derved blev Grundtvig endnu nærmere knyttet til Fribert-slægten, og da Lorentz Fribert i 18 io bekostede mindesmærket på Odden kirkegård over de faldne fra orlogsskibet »Prins Christian«, var det en selvfølge, at hans slægtning N.F.S. Grundtvig, den eneste digter i dette milieu af præster, proprietærer og landøkonomer, leverede indskriften.

I sidste halvdel af marts 1805 rejste Gr. fra Udby via Korsør til Langeland, som han atter forlod 1808. Da vi alene undersøger Gr.s københavnsadresser, bliver spørgsmålet først: hvornår i 1808 kom Gr. til København. Svaret er ikke svært, thi han oplyser selv i et brev af 4 . juni I808 til P.N. Skovgaard (Breve I, nr. 7), at »Voldborg Dag kom jeg hid«, dvs. I. maj (Valborgs dag). Rejsen gik over Lolland (jf. Poet. Skr. I, s. 352), men vi ved ikke (modsat Rønnings påstand: II, I, s. 58), om han på denne tilbage- 
rejse besøgte Torkilstrup og Udby. Også Rønnings påstand om, at Gr. forlod Langeland omkring midten af april, er ganske ubevist. Rønnings grundlag er her et brev fra Vedel Simonsen til Rasmus Nyerup, et brev, som han alene henviser til, men ikke citerer. Det er måske værd at anføre dette brevsted. Vedel Simonsen skriver i et brev af 22. maj 1808 fra Elvedgaard til prof. Nyerup i København følgende: »Cand: Grundtvig har forladt Langeland i Slutningen af April, for at gaae til Kiøb:, hvor jeg formoder han alt er ankommen; med mindre han endnu skulde opholde sig hos sin Fader, Præst i Egnen af Wordingborg el: sin Broder, Provst paa Falster« (Additamenta 17. fol.). Vedel Simonsens ord »Slutningen af April« er ikke en formodning, men et faktum og strider altså klart mod Rønnings »omkring midten af april« som afrejsetidspunkt. Rønning har naturligvis villet afsætte tid for Gr. til først at besøge Udby (eller broderen på Falster), så at han har kunnet nå at ankomme til Kbh. den I. maj, og Rønning gør dette besøg til et faktum, skønt det hos Vedel Simonsen kun er en hypotese.

Det blev ovenfor nævnt, at der var gået $3^{1 / 2}$ år, siden Grundtvig sidst havde været i København. Poetisk udtrykte han det således:

Atter kom jeg da tilbage,
Axelstad igjen jeg ser;
Trende Aar har mange Dage,
Og halvfjerde endnu fler.

(Poet. Skr. I, s. 355).

Den lange tid havde gjort ham venneløs ved tilbagekomsten. Hvad der mest glædede ham i den bomberamte by, var, at Trinitatis kirke med universitetsbiblioteket på kirkeloftet var sluppet uskadt over bombardementet (jf. Poet. Skr. I, s. 357), thi nu gjaldt det for Gr. om at skabe sig et navn som videnskabsmand og forfatter, og hertil var biblioteket ham uundværligt. Årene på Langeland synes han at have betragtet som et udenlandsophold, - idet han sammenligner sig med Gunløg Ormstunge, der også var tre år udenlands, inden han fandt hjem til Helga (Lise Blicher, jf. Poet. Skr. I, s. 42 I).

Som bekendt blev Gr. kort efter, den 25. maj I808 optaget som alumne på Valkendorfs kollegium, hvortil han vel ikke længe efter er flyttet hen. Men hvor han har boet i maj måned, før han fik kollegiet, vides ikke foreløbig. Et brevfund, med bevaret adresse, vil måske engang opklare det.

Valkendorfs kollegium lå dengang som nu i Sct. Pedersstræde, men selve kollegiebygningen lå på Gr.s tid ud til gaden, i flugt med selve gadens husrække $\left.{ }^{4}\right)$. Her boede Gr. i fulde tre år, men en nærmere skildring af dette ophold falder uden for denne undersøgelses rammer. Også de forskellige afbrydelser i opholdet, især omkr. I8ı-I I (krisen), skal vi ikke her komme ind på.

Gr. fik kollegiet for tre år, og det slog heldigt til, at han omtrent ved det tredie års udløb blev udnævnt til kapellan i Udby. Kort efter pinse rejste han til Udby for at tiltræde sin præstegerning. Selve pinsedagen (2. juni) synes at have været sidste dag på kollegiet, jf. digtet »Farvel til min Ven F. C. Sibbern« (Poet. Skr. I, s. 322 ff.).

4) I 1865-66 nedreves den gamle bygning, og en ny rejstes længere inde på kollegiets grund. 
Da Gr. alene var personel kapellan, kunde han regne med at blive tjenstledig ved faderens død, som kunde forudses at ville indtræffe inden alt for længe. Gr. vilde da blive brødløs, og dette er vel forklaringen på, hvorfor han ikke giftede sig i 18 r. Faderen døde 5. jan. 1813, men Gr. fungerede foreløbig videre, indtil en efterfølger blev ansat. Det trak noget ud, men den 15 . aug. 1813 kunde Gr. holde sin afskedsprædiken. Den 21. i samme måned rejste han til København, hvor han i sept. var i audiens hos kongen. Den 27. sept. vendte han hjem til Udby, og den 27. oktober fandt den endelige udflytning fra Udby sted. Rimeligvis har han ledsaget sin moder til Præstø; thi vi ved, at han først den 29. okt. (jf. Gr.s almanak for 1813 , se Gr.-Studier I955, s. 78 f.) med Lise rejste til København.

Under besøget i København i aug.-sept. boede Gr. i Store Strandstræde nr. 78, 2. sal (nuvær. nr. 20), en adresse, som kendes fra et brev til Gr. fra svigermoderen fru Mette Blicher (der da opholdt sig på landet) den 28. aug. 18I3 (fasc. 47I). Og samme sted boede Gr. også i den første tid efter udflytningen fra Udby, hvilket ses af udskriften på et brev fra svogeren P. E. Glahn til Gr. II. nov. (fasc. 474), hvor det om brevet hedder, at det »aflægges paa Hiørnet af Strandstræde og Garnisons Plads hos Hr. G. A. Schmidt«. Dette kan kun betyde, at Gr. har boet hos Schmidt, en af hans svogre. Det var ikke, som to Gr.-forskere antager ${ }^{5}$ ), Gr.s svigermoder, der boede i Store Strandstræde, thi hendes adresse var dengang Holmens Kanal nr. 254, hvilket vides fra vejviseren samme år (udkommet i febr. 1813, jf. Dansk Litteratur-Tidende 1813, s. I43).

Christian August Schmidt (1780-1853) havde i maj I812 ægtet Lises søster Anna Pouline Blicher ( $1785-1880$ ). Han var handelsuddannet, først handelsbogholder, senere grosserer. Mærkeligt nok dukker han først op i vejviseren for 1816-I7 (boende i Vingaardsstræde 136 , en adresse, vi senere skal møde et par gange), men det vides, at han har boet i Kbh. flere år før. Fra 1818-19 er hans bolig Nyhavn højre side nr. 276 (nuvær. nr. 12), og her boede han resten af sit liv. Til ægteparret Schmidts sølvbryllup i 1837 skrev Gr. tre sange (Poet. Skr. VI, s. 165-I68), af hvilke vi erfarer, at Schmidt sidder $\mathrm{i}$ gode kår, har forstået at tjene penge, så at han bl. a. kan bekoste en smuk sølvbryllupsfest. Ved denne var bl. a. alle fire Blicher-døtre til stede, de »falsterske Søstre«, som Gr. undertiden kaldte dem, altså ikke blot fru Schmidt og fru Lise Grundtvig, men også fru Bodil Marie Glahn og den ugifte »tante Jane«. Han havde sværmet for dem alle fire i sin tidlige ungdom, mest for Bodil Marie, som han aldrig glemte. Det livslange ømt-venskabelige forhold mellem Gr. og familien Glahn stammer herfra.

Gr. boede dog kun et par uger i Store Strandstræde. På et brev af 26. nov. I813 (jf. G. Albeck: Omkring Gr.s Digtsamlinger 1955, s. I67) finder vi en ny adresse: Holmens Kanal nr. 254, 2. sal (nuvær. nr. 22), hans svigermoders førnævnte bopæl. Gr. må være flyttet dertil i tiden mellem II. og 26. nov. I8r3; nærmere tidspunkt foreløbig uopklaret.

Provstinde Mette Blicher (1751-1826) var i 1805 blevet enke med seks

5) Rønning (II, 2, s. 50) og Gustav Albeck: Omkring Gr.s Digtsamlinger, 1955, s. $166 \mathrm{f}$. 
voksne eller næsten voksne børn. Hvornår hun har taget ophold i København, er uvist, men vi finder hende første gang i vejviseren for 1813 , hvad dog ikke kan tages som bevis på tilflytning omkring dette tidspunkt. Hos fru Blicher boede - som adskillige brevadresser viser - Gr. nu en kortere tid. Endnu i april 1814 bor han der, idet vi finder denne adresse under en bekendtgørelse af Gr. i Adresseavisen for 4. april, se herom Grundtvig-bibliografiens nr. 228. Men senere i dette år, senest i september, har han - som adresser på flere breve viser - fundet sig en ny bopæl, nemlig i Kronprinsessegade nr. 402, 3. sal (nuvær. nr. 44). Dermed forlod han sin svigermoder, som endnu et par år blev boende ved Holmens Kanal.

I Kronprinsessegade havde Gr. vistnok (og for første gang) sin egen lejlighed. Vi erfarer nemlig (da han i maj I818 flytter derfra), at han i 4 måneder har haft en hr. Schatt med kone og barn boende hos sig $\mathrm{i}$ et værelse, som han udlejede til dem (jf. brev fra Schatt i fasc. 523.38). Nu kommer Gr. også for første gang i vejviseren (i bindet for 1816-17, udsendt marts 1817), vistnok atter et bevis på, at han boligmæssig er blevet sin egen herre.

Årene i Kronprinsessegade blev en af de rigeste perioder i Gr.s forfatterskab. Her blev Verdenskrøniken 1817 og det meste af Saxo- og Snorreoversættelserne til, flere digtsamlinger, tidsskriftet Danne-Virke osv. osv. Men samtidig hørte disse år til de fattigste i hans liv, økonomisk set. Særlig sort så det ud i 18 17. Mod slutningen af dette år var hans gæld vokset til $2000 \mathrm{rdl}$. (Breve I, s. 498), og denne fatale situation er vel forklaringen på, hvorfor hans (tilkommende) svigermoder allerede i 1816 flytter hen til ham. (Dette ved vi bl.a. fra Vejviseren 1816-I 7, hvori vi fra nu af finder hende angivet med samme adresse som sin svigersøn). Ligeledes må den føromtalte udlejning af et værelse have samme forklaring. Det, man kalder »forstand på penge« eller »økonomisk sans «, besad Gr. ikke i videre grad, hvad han selv talrige steder indrømmer, og heller ikke hans forfatterskab i disse år har bragt ham økonomiske fordele. Således forholdt det sig forøvrigt gennem hele hans liv. »Dersom jeg blot skulde have levet af min Pen, maatte jeg have sultet ihjel for mange Aar siden « udbryder han i en rigsdagstale i 1850. - Nøden i 1817 skyldtes vistnok især, at honorarerne for arbejdet med krønikeoversættelserne en tid lang helt udeblev. Til sidst var der kun den udvej at søge kongen om hjælp. »I fem Aar «, skrev han til kongen i slutningen af $18 \mathrm{I}$, 》har jeg Intet havt at leve af uden det Lidet jeg... kunde tjene ved Skrifter, og hvad der gaves mig af enkelte ædelmodige Venner $\left(\right.$ Breve I, s. 498) ${ }^{1}$ ).

Men da nøden var størst, var hjælpen nærmest. Kongen tilstod ham fra og med 1818 en årlig understøttelse på $600 \mathrm{rdl}$., just ikke meget, men dog et grundlag, som han kunde bygge videre på. Nu turde han tænke på ægteskab og dermed også på en ny bopæl.

1) Både dengang og senere har venner og bekendte af Gr. undertiden spekuleret på, hvad han i grunden levede af. Den norske biskop Claus Pavels skriver i sin dagbog for 1817 om Gr., at han »menes at tære paa sin Fædrenearv《. Denne arv havde dog statsbankerotten forlængst bragt til at smuldre. 
I818 blev flyttemæssigt et opbrudsår for flere af de i det foregående omtalte personer. I maj flytter Gr. til Vingaardsstræde nr. I36 (nuvær. nr. 9). tidsbestemmelsen tør vi ret sikkert udlede af det føromtalte brev fra hr. Schatt, dateret 27. maj. Denne skriver nemlig, at han forgæves har søgt Gr. i hans (nye) bopæl for at betale den leje, han skyldte ham, og det er tydeligt, at flytningen må være foregået for ikke mange dage siden, altså engang i maj 1818. Endnu i marts har Gr. den gamle adresse; i juni og juli finder vi på flere breve den nye. Bopælen $\mathrm{i}$ Vingaardsstræde må have været svogeren G. A. Schmidts lejlighed, som denne samme år fraflyttede, idet vi af vejviseren 1818-i9 (udsendt i sept. 1818) ved, at han fra nu af bor i Nyhavn, som tidligere oplyst. Også svigermoderen flyttede med Gr. til Vingaardsstræde, thi både han og hun har denne adresse i vejviseren for 1818-19.

Men for Gr. var denne ordning rent midlertidig, thi han skulde giftes samme år, hvorefter meningen var, at han og Lise skulde sætte bo for sig selv. Og således gik det da også. Den 18. aug. lod Gr. sig i Ulse kirke vie til Lise, og begge rejste kort efter til hovedstaden, hvor de først nogle dage tog ophold i Vingaardsstræde (jf. brev nr. 192 i Breve I) og derefter, i slutningen af samme måned, rykkede ind i deres egen bopæl i Løngangsstræde nr. I68 (nuvær. nr. 29). Svigermoderen, som havde været bortrejst, fik nu ordnet lejligheden i Vingaardsstræde, hvor hun blev boende til sin død i 1826.

Bopælen i Løngangsstræde betegnes på et brev til Gr. fra vennen Chr. Olsen den 31. okt. I8I8 (fasc. 457) således: »Løngangsstræde lige over for Vartou Kirke hos Snedkeren «, og på et andet brev fra samme (22. febr. 1819): »Løngangsstrædet hos Snedkeren lige over for Vartou Kirke iste Sahl $\ll$.

Snedkerboligen (og rimeligvis også et værksted) fandtes i stueetagen i den opgang, hvor Gr. boede. Iflg. folketællingen I8o I levede her en snedkermester Carl Tramburg, men i 1818 bor han i Vognmagergade. Om han på dette tidspunkt har ejet værkstedet i Løngangsstrædet, er foreløbig uvist.

Det har sikkert været en meget lille og billig lejlighed, Gr. her beboede; mere tillod de 600 årlige rigsdaler ikke. Brun kan oplyse, at »Jeg hørte selv engang Gr. fortælle, at, da han var bleven gift, boede han saa trangt, at da Ingemann kom og besøgte ham og saa hans Studere-Kammer, sagde han: Naar Du skal sidde her og skrive, maa Du vel sætte Stolen i det andet Værelse.« (Brun: Gr. I, s. 6I). Det har altså været småt bevendt med pladsen. Og hvad har Lise mon tænkt om denne bolig efter syv års forlovelse?

Gr.s Løngangsstræde-adresse har opnået en vis berømmelse i vor litteratur. Omkring den tid, da Gr. giftede sig, udspilledes den bekendte litterære fejde »Tylvtestriden«. Det berømteste indlæg i denne, det, som eftertiden husker bedst, var Poul Martin Møllers »Himmelbrev«, hans vittige og muntre parodi på Gr.s sprog og stil i disse år. Heri lader Poul Møller Gr. være forfatter til et brev til Baggesen-modstanderne, hvori denne (Gr.) ønsker dem udelukket af litteraturen. Brevet slutter med ordene: »Givet paa vor Residents udi Løngangsstrædet, ligeover for Vartov Kloster«. - I Løngangsstræde fortsatte Gr. sit uhyre flittige studieliv, arbejdende dag og nat, så at han fik ry for at være en meget utilgængelig person. Da tre tilhængere af Gr., Dampe, Repp og Jacob Christian Lindberg under fejden vilde henvende sig 
til Gr. for at bede ham tage Baggesens parti, fulgtes de ad hen ad Løngangsstræde, men da »de kom til Porten, vovede Repp og Dampe sig imidlertid ikke videre. Gr.s Inkommensurabilitet og Kolossalskhed gjorde ham jo til en Slags Bussemand. - Lindberg gik da ene op, medens de andre To stode i Porten saalænge«. Han »fandt Saxos og Snorros geniale Oversætter i den Grad indhyllet i Røg og Damp, at han kun utydeligt kunde skimte den mærkelige Mands Skikkelse. Gr. modtog Lindberg venligt; og da han hørte hans Ærinde, sagde han, at han virkelig havde tænkt paa at rykke Baggesen til Undsætning « (Kr. Arentzen: Baggesen og Oehlenschläger VII (1877), s. I29 f.; Arentzen har vist nok sin viden om dette fra Niels Lindberg, Jac. Chr. Lindbergs søn).

I Løngangsstræde blev Gr. kun boende til begyndelsen af I820. Endnu i slutningen af januar nævnte år bor han dér (brev fra moderen 28. jan., fasc. 422), men den 20. febr. har han en ny adresse: Kronprinsessegade nr. 388 (nuværende nr. 12), jf. et anonymt brev af denne dato i fasc. 422. Ligeså i vejviseren for 182 I (udsendt i febr.). De nærmere omstændigheder ved dette bopælsskifte kender vi ikke. På det nye sted bor han godt og vel et år, thi i februar I82 I kaldtes han til præst i Præstø og Skibbinge. I april tog han derned for at se sig om efter en passende bolig, og ved pinsetid, omkr. Io. juni, kunde den endelige flytning finde sted. I Torvestræde i Præstø fandt han og Lise deres nye hjem, og der fødtes deres første søn Johan Gr.

Vi standser her foreløbig denne lille oversigt over Gr.s bopæle. Når vi ser tilbage på det her behandlede afsnit af hans liv, specielt årene I808-21, og konstaterer den påfaldende hyppighed, hvormed han skiftede adresse, vil man uvilkårlig søge en forklaring herpå. Man kunde fristes til at tro, at også her afspejlede det ydre det indre, det mangesidige, adspredte forfatterskab kunde have sit tilsvarende $\mathrm{i}$ en ydre uro osv. Men denne betragtningsmåde er sikkert forkert. Snarere tror vi, at Gr. med sit uhyre gærende indre, hans optagethed af store, almene ideer har gjort ham ganske ligegyldig for den nære, materielle omverden: han har netop ikke bekymret sig videre om, hvor eller hvordan han boede eller i det hele om penge og karriere i borgerlig forstand. Dette er rimeligvis forklaringen på hans tilfældige opholdssteder, snart logerende hos familie, snart alene. Borgerligt set var han indtil I82 I den typisk fattige litterat og kapellan, der gennem mange år måtte »holde sig ved haab i live«, indtil han langt om længe kom i stilling. For så vidt førte han i hele sin ungdom en temmelig uborgerlig tilværelse, skribentens og den tjenstledige teologs usikre lod. Og det skulde siden vise sig, at heller ikke ægteskab og præstestilling kunde binde ham. Skønt fader til to små børn opgav han som bekendt sit embede i 1826 for atter en tid lang at leve som fattig, men fri videnskabsmand og skribent.

Efterskrift. Under trykningen af ovenstående afhandling har jeg fundet et par småoplysninger af Gr. om Thomas True og Peter Bøgild, endvidere en af mig uomtalt bopæl under Gr.s studentertid. Nærmere herom i næste (afsluttende) afsnit. 